\title{
Chunking, Elaborating, and Mapping Strategies in Teaching Reading Comprehension Using Content Area Materials
}

\author{
Lilies Setiasih ${ }^{1, *}$ \\ ${ }^{1}$ Bandung Islamic University, West Java, Indonesia \\ *Correspondence: Komplek Margahayu Permai MC III/ 206A, Kopo, Bandung, West Java, Indonesia. Tel: \\ 62-813-9475-1253.E-mail: lies_hadi@yahoo.com
}

Received: January 13, 2015

Accepted: February 5, 2015 Online Published: February 14, 2015

doi:10.5430/wjel.v5n1p32

URL: http://dx.doi.org/10.5430/wjel.v5n1p32

\begin{abstract}
This paper reports on an experimental study of the application of chunking, elaborating, and mapping strategies in teaching reading comprehension using content area reading materials. The research method employed a pretest-posttest control group design. The purpose was intended to answer the research problem related to the effect of the treatment on the students' English reading achievement. The hypothesis proposed was that there was no difference in reading achievement scores of the two groups before and after the treatment. The subjects of the research were the first year students at the Economics Faculty, Bandung Islamic University, Indonesia. The research instruments were reading comprehension tests covering micro processes, integrative processes, macro processes, and elaborative processes. The data obtained through pretest and posttest, were statistically analyzed using $t$-test. The study showed that the treatment had a significant effect on the students' reading achievement. In addition, the students in both groups were asked to fill in questionnaires to identify their perception on the trained reading strategies and teaching materials. The study indicated that their perception was mostly positive. In brief, this study suggests that chunking, elaborating, mapping, and summarizing strategies facilitate students' reading comprehension in expository texts in the Indonesian context. However, further research utilizing different reading strategies should be conducted to explore other outcomes that might be more effective in EAP classrooms.
\end{abstract}

Keywords: chunking; elaborating; mapping strategies

\section{Introduction}

The increase of information transfer has made English as an important tool of global communication. One of the impacts of this condition is tighter competition among the university graduates in labor market. The proper English proficiency often becomes one of the requirements for them to be able to win in the competition. Therefore, to improve university students' English proficiency, English is still taught in non-English departments at the university level in Indonesia.

The teaching of English in universities in Indonesia as a continuation of teaching in high schools is more specific in nature. In non-English departments, it serves as academic purposes especially to equip university students with the ability to acquire knowledge in their field of studies (Sadtono, 1997). The English credit loads in non-English departments in the university level range from two to four credit hours. The existence of English subject indicates that English is still considered to be one of the important subjects. This is, of course, with the hope that the English teaching in universities would be more satisfying in fulfilling students' needs. This is really a challenge for a lecturer to think and to act more professionally in realizing this policy. The professionalism here means that the lecturer should select appropriate teaching materials and techniques based on theoretical principles and empirical studies in order to fulfill the students' needs.

Two reasons for doing the research are: (1) the reading English proficiency of the students in the university where the research was conducted was still low. The low proficiency of English was indicated by the average scores of English in their national high school examination; (2) the reading skills in content area were considered to be of great importance for the students because many lecturers required the students to read the textbooks and journals written in English. The students' incapability to read textbooks written in English and the students' needs to be able to read 
them resulted in a gap. Explicitly, on the one hand, the majority of undergraduate students still had difficulty in reading the content area textbooks written in English. On the other hand, they needed to be able to read them. Therefore, English lecturers should make alternative efforts to overcome the problem and to help students improve their reading skills. With this in mind, an experimental study applying specific reading strategies in the teaching of reading comprehension using materials in the field of Economics and Business was conducted in the faculty of Economics at Bandung Islamic University.

The major purpose of this study was to find out the effectiveness of the trained reading strategies comprising chunking, mapping, elaborating, and summarizing strategies. Thus, the research question was: "Is there any effect of the treatment on the students' English reading achievement?" As the additional information, at the end of the experiment, the students in both groups were asked to fill in questionnaires. This was intended to identify their perception on the trained reading strategies and teaching materials. The results of the study are expected to contribute to the teaching of EAP in particular in Indonesia and English teaching profession in general.

\section{Literature Review}

The importance of reading competence in an academic context has been reported by many researchers (e.g., Bright \& McGregor, 1986; Eskey, 2002; Grabe, 1994; McKenna \& Robinson, 1993; Paul, 2007). Grabe (1994) stated, "Reading is the most important skill for language learners in academic contexts. It is the core of the syllabus because by reading a book most students learn" (p.137). Meanwhile, Bright and McGregor (1986) have claimed, "Only by reading can students acquire more knowledge when they intend to learn new content in their discipline and when they leave schools" (p.52). Roe, Stoodt, and Burns (1987) have stated, "Students cannot learn unless they can comprehend reading material, and they cannot remember what they have read unless they have understood them" (p.80). Furthermore, these opinions are supported by McKenna and Robinson (1993) who have stated that the ability or skills to use reading and writing to acquire new content within learners' subject area or discipline are needed (p.12).

Paul (2007) has claimed, "EFL learners need to read and write in order to deeply internalize the English they learn" (p.83). At last, university students need to have efficient reading skills to comprehend a great number of materials in their studies (Soranastaporn, 1999). In brief, reading skills are important for students in academic contexts because through the ability of reading the students can develop their knowledge and skills essential for independent learning and their quantity and quality of reading determine their professional competence and further education.

\section{Reading Comprehension, Reading Skills, and Reading Strategies}

Reading is "the process of constructing meaning through the dynamic interaction among the reader's existing knowledge, the information suggested by the written language and the context of the reading situation" (Bergeson, Mayo, Lawson, \& Miller, 1998, p. 6). Goodman (1970) firstly considered reading as a "bottom up" process (as cited in Brown, 1994) in which the reader advances in linear fashion from letters to words to sentences to meaning (p.284). Then, Goodman and Burke (1972) argued that reading was described as a "top down" process (as cited in Nunan, 1998) in which the reader samples the text, using background knowledge to predict and make hypotheses about words and meaning (p.65). The current understanding is that reading is "recursive and interactive and includes both bottom up and top down processing" (Bergeson et al., 1998, p. 6). While reading, a reader transacts with a text, processes visual information, relates it to background knowledge, and constructs a meaning that approximates the author's intended meaning.

According to Lipson and Wixson (2003), "Reading comprehension is the ability to use previously acquired information to construct meaning for a given text" (p.23). Some researchers (Bright \& McGregor, 1986; Irwin, 2006; Long \& Richards, 1987; Willis, 1986) have posited that comprehension is an active process which involves understanding and selectively recalling ideas in individual sentences, inferring relationship between clauses and/or sentences, organizing ideas around, relating prior knowledge with those ideas, summarizing ideas, and making inferences. These processes work together and can be controlled and adjusted by the reader as required by the reader's goals and the total situation in which comprehension is taking place. In a slight different statement, Roe et al. (1987) have clarified that the essential reading skills and abilities needed in reading content materials were summarized, among others, as follows: understanding special concepts and vocabulary; identifying main ideas and supporting details; locating facts or specific details; organizing reading material by determining sequence, drawing conclusions, and finding cause-and-effect relationship (pp. 122- 207). In other terms, Irwin (2006) interpreted 
reading comprehension as a process involving "micro processes, integrative processes, macro processes, elaborative processes, and metacognitive processes" (p.9).

Although many writers explain reading skills in different ways, the ideas are similar. The reading skills required in reading content materials principally, among others, include understanding main ideas and supporting ideas intended by the author, relating prior knowledge with those ideas, evaluating, and making inferences and flexible adjustment of strategies used to comprehend the reading text. With this in view, reading is a dynamic and interactive process in which a reader works actively to construct meaning from the text. While reading, the reader automatically selects appropriate strategies to interpret information.

The understandings of reading comprehension, then, imply that the purpose of teaching reading is to help students acquire reading skills to become independent learners and, therefore, the method and strategies of teaching should be directed to achieve it. Chastain (1989) has stated, "The ultimate objective of teaching reading comprehension is to enable the students to comprehend written text which is considered appropriate to their level" (p. 86). The levels of reading comprehension may be literal, inferential, evaluation, application and appreciation (Alexander, 1989; McKenna \& Stahl, 2009; Roe et al., 1987) depending on the students' academic level. In line with Musthafa's idea (1997), "the purpose of teaching reading should primarily be helping students acquire the strategies needed for comprehending the materials to acquire new knowledge in their subjects" (p. 37).

Based on several studies, Prapphal (2003) has summarized, "Reading comprehension can be facilitated by explicitly teaching readers about expository text structure and by teaching various strategies for identifying and utilizing that structure during reading process" (para. 3). Furthermore, many studies in which novice readers were trained to use the strategies, such as inferencing, identifying important information, monitoring, summarizing, and question generating, have shown very promising results (Sweet, Riley, Robinson, \& Conaty, 1993).

The reading strategies taught in English for Academic Purposes (EAP) class using students' specialist texts might benefit less-skilled readers in comprehending EAP texts. English for Academic Purposes (EAP) can be said to relate to the study of discipline, such as science, social studies and other academic disciplines (Richards, 2001, p. 33; Strevens, 1983, p. 91). The purpose of the EAP course is to enable the students to function adequately in a target situation. The target situation here means "the situation in which the students will use the language they are learning" (Hutchinson \& Waters, 1987, p. 8).

According to Vacca and Vacca (1993), "Texts are important tools in the development of independent learners and they might represent a single written word, a paragraph, several pages, a chapter, or an entire book" (p. xiii). The standard way of achieving the independency of the learner is to take texts from the learners' specialist area (Hutchinson \& Waters, 1987). Based on Hudson's study (1991), cited in Prapphal (2003), it has been demonstrated that "the content comprehension approach can improve reading comprehension as well as knowledge of reading grammar and general ability to read English for science and technology" (para.4). Thus, the first stage in any EAP course is to find out exactly why the students learn English and what language skills they need. The purpose of English teaching at the Economics faculty where the research was conducted was to help students acquire reading skills in English to become independent learners. With this in mind, the strategies of teaching in this study were directed to achieve it and the reading texts were taken from the students' discipline; Economics, Management, and Accounting. Meanwhile, the reading strategies employed included those discussed in the research method.

\section{Research Method}

This was an experimental study using a pretest-posttest control group design. There were two groups — an experimental group which received the special treatment and a control group which did not. The samples were randomly assigned to one or the other group, and the decision as to which group was the experimental group was also randomly determined (Hatch \& Farhady, 1982, p. 22). Each group consisted of thirty students. Thus, the research design was as follows:

\section{$\frac{G 1(\text { random }) T 1 \times T 2}{G 2(\text { random }) T 1 T 2}$}

The treatment, conducted during ten teaching sessions, was training specific reading strategies to the experimental and control groups. The reading texts were taken from the students' specialist. Here are the strategies trained in both groups. 
Table 1. Differences of Trained Strategies between Experimental and Control Groups

\begin{tabular}{lll}
\hline \multicolumn{1}{c}{ Experimental Group } & \multicolumn{1}{c}{ Control Group } \\
\hline 1. & $\begin{array}{l}\text { Activating prior knowledge (Elaborative } \\
\text { Processes) }\end{array}$ & 1. Not trained \\
2. Previewing/surveying (microprocesses) & 2. Previewing/ Surveying (microprocesses \\
3. & Chunking Strategy (microprocesses) & \\
4. Reading for main ideas (macroprocesses) & 3. Not trained \\
5. Scanning (microprocesses) & 4. Reading for main ideas (macroprocesses) \\
6. Locating references (integrative processes) & 5. Scanning (microprocesses) \\
7. Mapping Strategy (macroprocesses) & 6. Locating references (Integrative processes) \\
8. Elaborating (Elaborative processes) & 7. Not trained \\
9. Making Inferences (elaborative processes) & 8. Not Trained \\
10. Monitoring (metacognitive) & 9. Making inferences (elaborative processes) \\
11. Writing the summary using the students' & 10. Monitoring (metacognitive) \\
& own words based on the chart of ideas or & 11. Not trained \\
& mapping strategy (reading-writing \\
&
\end{tabular}

It is shown in Table 1 that the students' prior knowledge in the control group was not activated before the reading activities. Then, chunking strategy, elaborating the ideas to the real life situation, mapping strategy using charts of ideas, and writing the summary or retelling the ideas using the students' own words based on the chart of ideas were not trained. Those strategies became the major points in the experiment for the following reasons. First, activating the students' prior knowledge as part of elaborative processes was important in reading comprehension. Reading comprehension is viewed as a process of relating the new to the known. Readers understand what they read only when it relates to what they already know (Grabe, 1994; Irwin, 2006; Nunan, 1998). Prappal (2003) has demonstrated that "language background in general English had an effect on language performance on the EAP achievement test" (para. 12). In this step, the focus was only to recall the students' prior knowledge related to the texts. Second, the chunking strategy was trained to the experimental group because the students had to understand that when they read, they read phrase by phrase as one meaningful unit not word by word. Chunking ability is the ability to group words into meaningful phrases/ units. According to Irwin (2006), "Poor readers benefit from chunking assistance" (p.18).

Third, elaborative strategy was emphasized to activate the students' prior knowledge about the world and to improve their critical thinking and logical reasoning. "Elaborations that integrate new ideas with past experiences clearly affect and improve recall and increase enjoyment" (Irwin, 2006, p. 74). Skill in reading depends on "the efficient interaction between linguistic knowledge and knowledge of the world" (Carrell \& Eisterhold, 1987, p. 220). In this step, the focus was to elaborate the ideas stated in the texts into the real life situations. Explaining, reasoning, and providing examples of the ideas intended by the author in the real life situations became the focus of discussion in the experimental group. Fourth, drawing a chart of the ideas of the text and summarizing were important to ensure that the students understood the text. The students selected an organized set of summary ideas or the most important information to remember by applying study guides or activities completed during reading. Selection and invention were created to summarize the text (Irwin, 2006), so at the end of the lesson they were able to summarize it using their own words. The importance of drawing the chart of ideas is supported by Roe et al. (1987) who synthesize that "organization of content is an important component of reading comprehension because comprehension is building bridges between the new and the known" (p.84). In addition, some researchers (Irwin, 2006), have found that readers who use the author's organizational pattern to organize their own memory of the passage actually recall more than those who do not. Mapping strategy is one way to encourage the students to construct a diagram of ideas or contents. At last, the steps of teaching in both groups followed genre-based approach, consisting of "building knowledge of the texts, modeling, joint construction of the texts, and independent construction of the texts" (Agustien, 2006, p. 17).

To find out the effectiveness of this model, there were tests before and after the treatment. The reading tests actually used two kinds of test, multiple choice questions and full answer questions which comprised four processes of reading comprehension; micro processes, integrative processes, macro processes, and elaborative processes (Irwin, 2006). In this paper, only the results of the full answer questions tests were reported. The pretest and posttest were firstly tried out to twenty students of Management department that had been randomly selected from the population. 
The criteria ranging from 0 to 3 were applied to score the results of the full answer question tests.

To find out the validity of the tests, criterion-related validity was used. The results of the test were correlated to the standardized test, in this case the English scores presented in the State Examination of High School (UAN). Concurrent validity as "one type of criterion-related validity is the validity where the test scores are correlated with another measure of performance" (Weir, 1990, p. 27). Thus, to find out the validity of the tests, the scores obtained through try-out pretest and try-out posttest were correlated to UAN scores. The correlation was .72 and .68. The coefficients obtained were high enough, meaning that the pretest and posttest were valid. In addition, to make sure the validity of the tests, the researcher used content validity by consulting the tests to an expert (A. Aziz, personal communication, January $\left.10^{\text {th }}, 2007\right)$ to judge that they measured what they were intended to measure. In short, the tests measured the students' English reading comprehension skills and the test questions reflected the comprehension skills.

To find out the reliability of the tests, the test-retest method was used. The scores of the tests were correlated. Reliability was obtained by administering the test twice to the same students randomly selected from the population. Then, it was found that all the tests were statistically reliable. Using Pearson Correlation, the reliability of the pretest was .98 and the reliability of the posttest was .93 . Hughes (1989) has stated, "A reliability coefficient of .98 might be considered high for reading test" (p. 32). If a test measures consistently, it is said to be reliable (Hughes, 1989). It means that there was a strong correlation between try-out test 1 and try-out test 2 . In addition, all test items in each test were analyzed using item analysis. However, the difficult items were not changed because those parts would be emphasized in the treatment. There was only little revision in the instruction. The conclusion was that the pretest and posttest were reliable. The following table shows the characteristics of the study.

Table 2. Characteristics of the Study

\begin{tabular}{|c|c|}
\hline Research hypothesis: & $\begin{array}{l}\text { There is no effect of treatment on reading achievement of the students or there } \\
\text { is no difference in the reading achievement scores of the two groups before } \\
\text { and after the treatment. }\end{array}$ \\
\hline Significance level & $0.5 ; 2$-tailed \\
\hline Design & Pretest and posttest control design \\
\hline Dependent variable : & Reading Achievement \\
\hline Measurement : & Scores (interval) \\
\hline Independent variables: & $\begin{array}{l}\text { Instruction of reading comprehension strategies } \\
\text { Independent measures }\end{array}$ \\
\hline Other feature: & random selection \\
\hline Statistical procedures: & $t$ - test \\
\hline
\end{tabular}

\section{Data Analysis and Discussion}

In the pretest-posttest control group design, the experimental group and the control group both received two sets of measurement conducted before and after the treatment. The symbolic arrangement of before after control group design was as follows.
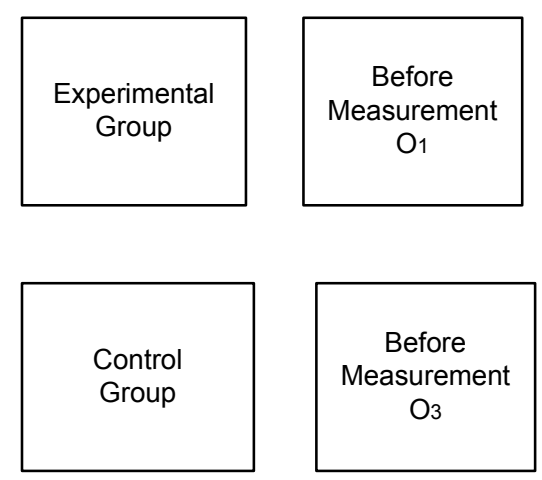

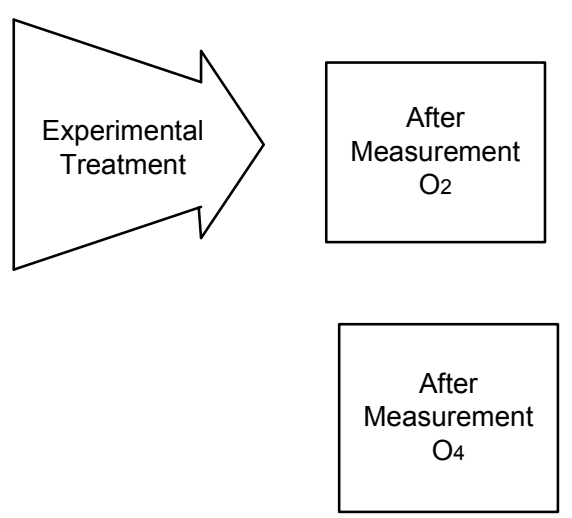




\subsection{Results of Pretest and Posttest}

The results of pretest and posttest (see Appendix A) became the major findings of the research and those of the students' perception on the trained reading strategies and the teaching materials were used as the additional data to complete the research results.

\subsection{Data Analysis and Discussion of the Pretest and Posttest Results}

The data, obtained through the results of pretest and posttest, were analyzed using $t$-test. To identify the normality of score distribution or value dispersion, the data were firstly tested using the normality test of Kolmogorov-Smirnov applying SPSS Ver. 10.0. Based on the statistical outputs, it was found that the data obtained through the pretest and posttest had normal distributions. It means that the data analyzed were dispersed in a normal curve. The results of the calculation are shown in Table 3.

Table 3. The Results of Statistical Calculation Using SPSS ver.10.0

\begin{tabular}{|c|c|c|c|c|c|c|}
\hline & & Group & $\mathrm{N}$ & Mean & $\begin{array}{c}\text { Std. } \\
\text { Deviation }\end{array}$ & $\begin{array}{l}\text { Std. Error } \\
\text { Mean }\end{array}$ \\
\hline Diff. & Score & Experimental Group & 30 & 22.5333 & 7.9034 & 1.4430 \\
\hline SAQ & & Control Group & 30 & 11.2000 & 7.9368 & 1.4491 \\
\hline
\end{tabular}

There were two steps to analyze the data. The first step was by verifying the equivalency of the variances through the following hypothesis:

$$
\begin{aligned}
& H_{0}: \sigma_{d_{1}}=\sigma_{d_{2}} \quad \text { Experimental variance is equivalent to control variance } \\
& H_{1}: \sigma_{d_{1}} \neq \sigma_{d_{2}} \quad \text { Experimental variance is not equivalent to control variance }
\end{aligned}
$$

Based on the outputs shown in Table 3, the mean of experimental group was 22.5333 and the mean of control group was 11.2000. Using Levene's test, the F value with equal variances assumed was .069 with the probability .793. If the probability was $>.05$, Ho was accepted and if the probability was $<.05$, Ho was rejected. The probability was $>.05$. It means that Ho was accepted. In other words, the experimental variance was equivalent to the control variance.

The second step was calculating $t$-value. The hypothesis proposed was as follows.

$\mathrm{H}_{0}$ : $\quad$ Pretest mean $=$ Posttest mean

$\mathrm{H}_{1}$ : Pretest mean $\neq$ Posttest mean

Ho: $\quad$ Mean of score differences between experimental group and control group was equivalent, meaning that the treatment had no significant effect on the students' reading achievement.

$\mathrm{H}_{1}$ : $\quad$ Mean of score differences between experimental group and control group was different, meaning that the treatment had a significant effect on the students' reading achievement.

By using SPSS Ver. 10.0, it was found that " $t$ " value with equal variance assumed for the tests was 5.542 and the probability was .000 . Statistically, if the probability is $<.05$, Ho is rejected. It means that the means between experimental and control groups were different. In other words, the study showed that the treatment had a significant effect on the students' reading achievement.

The strength of the association was calculated using Hatch's and Lazaraton's formula (1991, p.265), and it was found .3462 . It indicated that $35 \%$ of the variability in this sample could be accounted for by the treatment. $65 \%$ of the variability could not be accounted for by the independent variable. In other words, the treatment was effective since the variability of individual achievement between two groups was small.

Based on the categorization of reading comprehension processes underlying the tests, the improvement of the students' reading abilities is shown in Figure 1. 


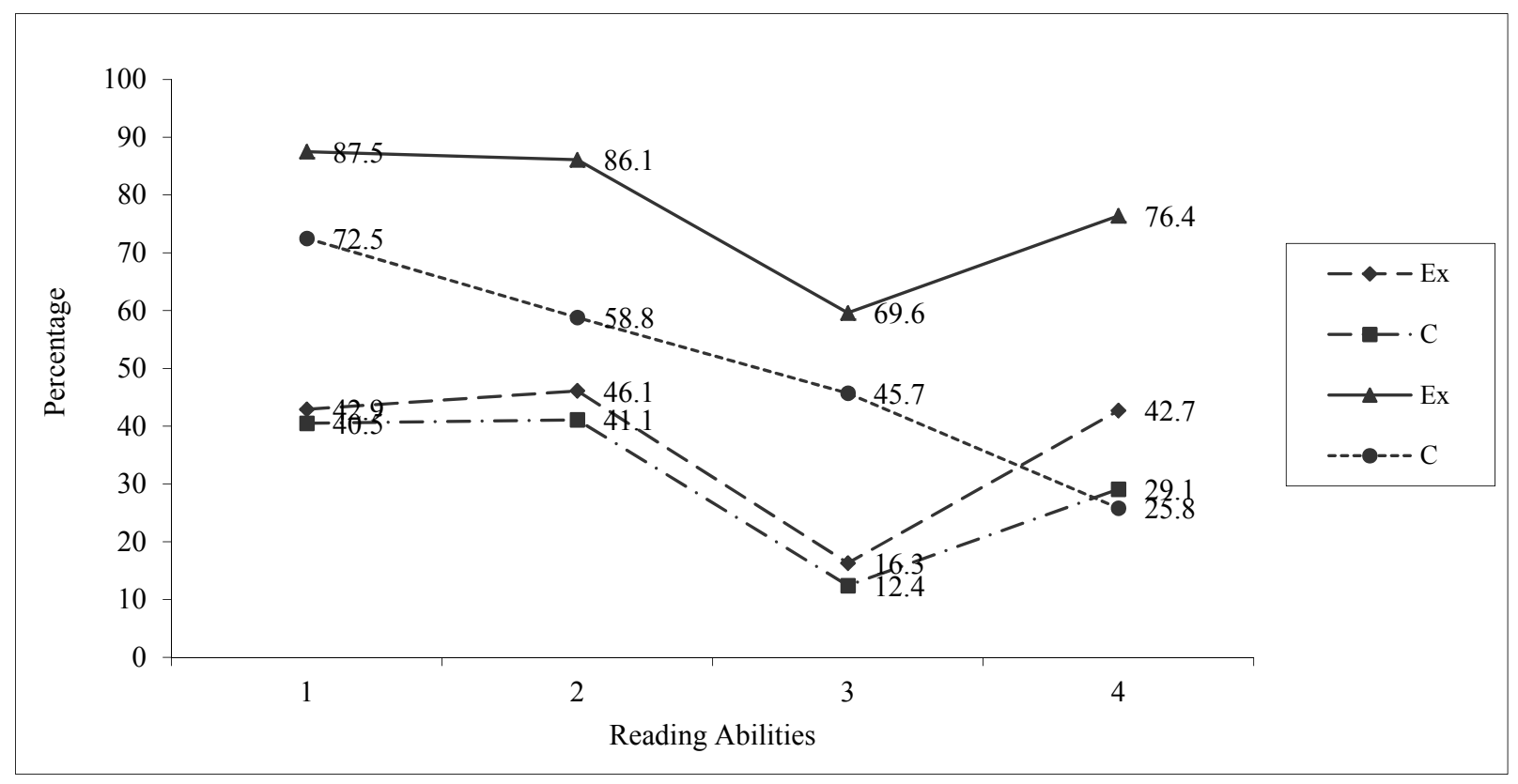

Figure 1. Chart of Students' Scores of Pretest and Posttest Based on Skill Categorization

Note: 1. Micro processes; 2. Integrative processes; 3 . Macro processes; 4.Elaborative processes

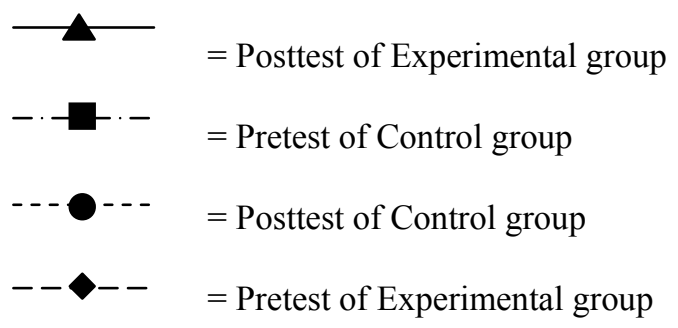

As shown in Figure 1, there was an increase of the percentage in the students' reading abilities in both experimental and control groups. The increase of the two groups, however, was different. The percentages of the experimental group in all reading skills were higher than those of the control group. The percentage of the elaborative skill in the control group was much lower than that in the experimental group. In short, the study indicated that the treatment had a good effect on the students' achievement in English reading comprehension in both groups but the effect of the treatment on the experimental group was bigger. The results, indeed, supported the significant statistic result.

\subsection{Results of Students' Perception on the Trained Reading Strategies and Teaching Materials}

After the experiment had finished, the students in both groups were asked to fill in the questionnaires. This was done to identify their perception on the trained reading strategies and the teaching materials, but this was not the major purpose of the research. As shown in Figure 2, the students' perception on the trained reading strategies and teaching materials. 


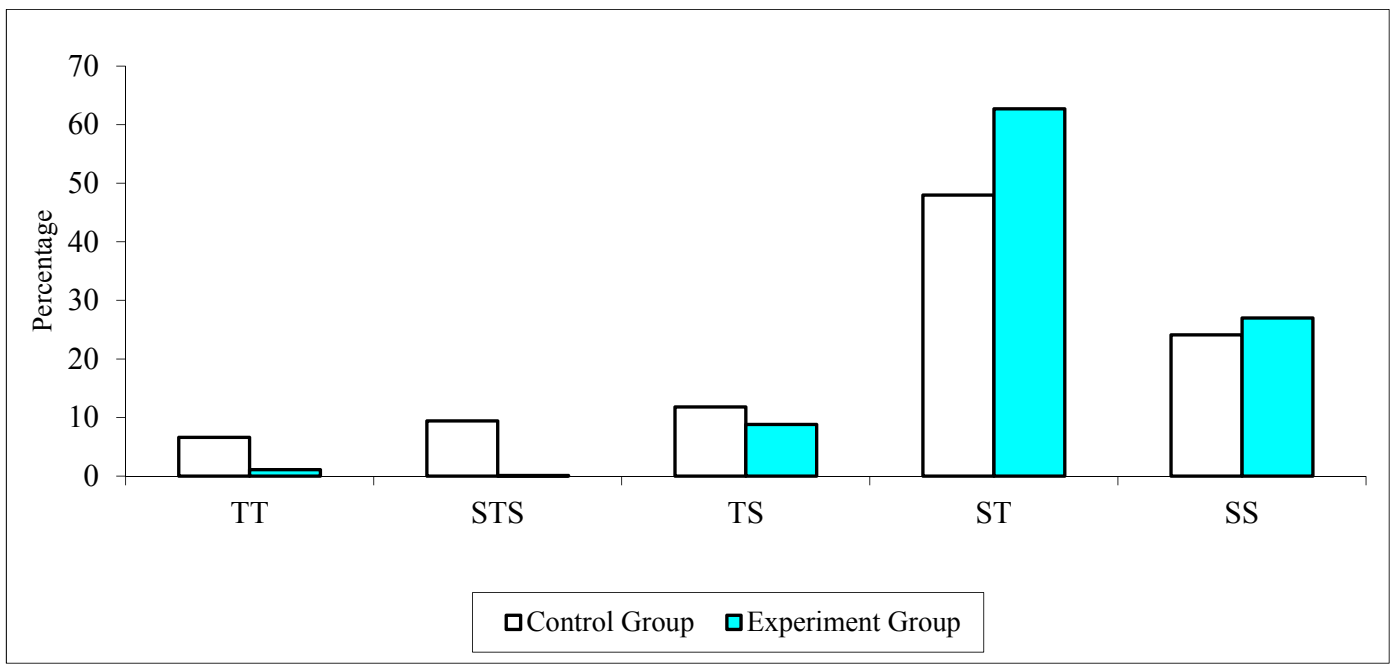

Figure 2. The Students' Perception on the Trained Reading Strategies

Note: TT (undecided), STS (strongly disagree), TS (disagree), ST (agree), and SS (strongly agree)

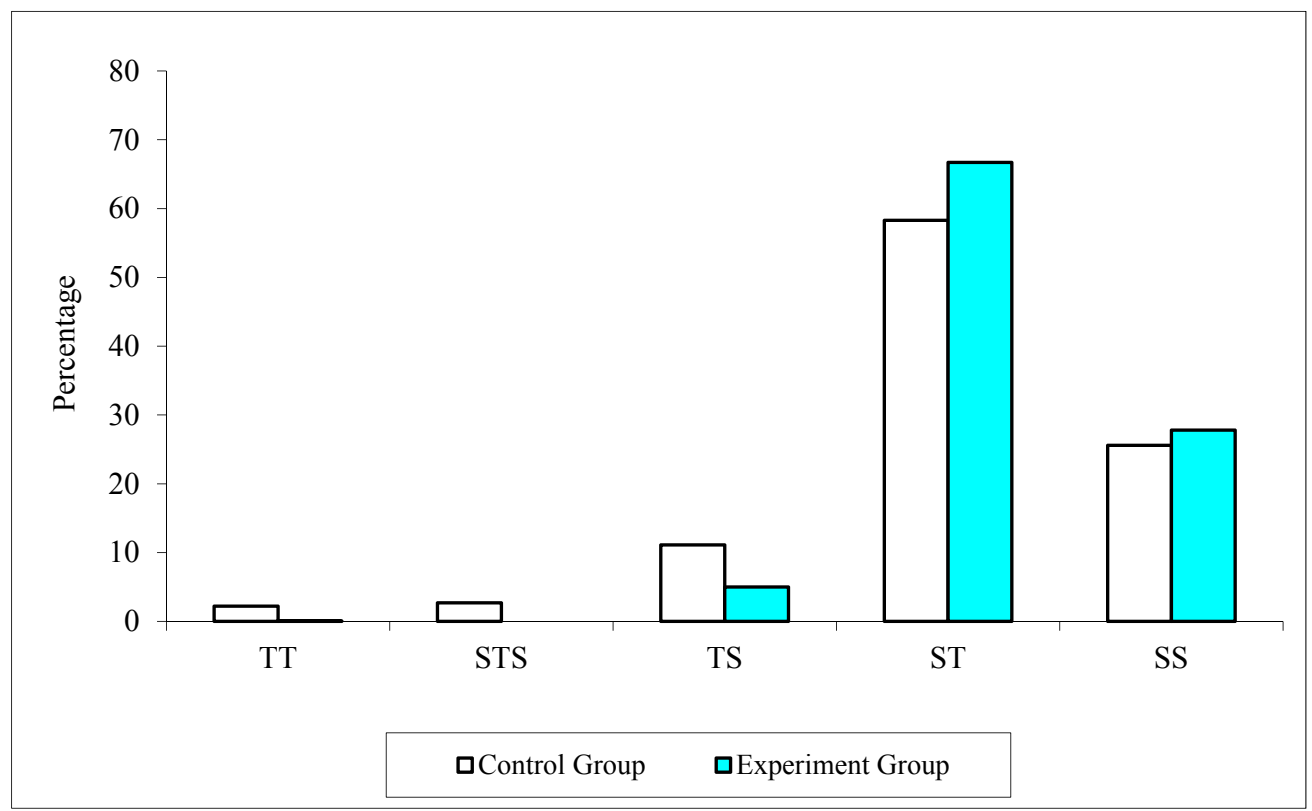

Figure 3. Students' Perception on Teaching Materials

5.4 Data Analysis and Discussion of Students' Perception on the Trained Reading Strategies and Teaching Materials

As shown in Figure 2, the percentages of the students stating positive perception on the trained reading strategies both in experimental group and control group were greater than those of the students stating negative perception. The positive perception in the experimental group was reflected in their responses stating 'agree' $(63 \%)$ and 'strongly agree' (27\%). The positive perception in the control group was reflected in their responses stating 'agree' (48\%) and 'strongly agree' (24\%). The differences of percentage between the experimental and control groups might be resulted from the difference of the trained teaching strategies. However, the experimental group tended to have more positive perception on the trained teaching strategies.

As shown in Figure 3, most students also had positive perception on the teaching materials. The percentages of the experimental group in the positive levels were greater than those of the control group. The positive perception in the experimental group was reflected in their responses stating 'agree' (67\%) and 'strongly agree' (27\%). The positive perception in the control group was reflected in their responses stating 'agree' $(58 \%)$ and 'strongly agree' $(25 \%)$. There was only a slight difference of percentage between the students' perception in the experimental group and that in the control group. It means that the teaching materials contributed to the students' needs as a whole. In brief, the 
study indicated that the students' perception on the trained reading strategies and teaching materials was, in general, positive. The percentages of the students stating positive perception were greater than those of the students stating negative perception.

\section{Conclusion and Implication}

In conclusion, the study showed that there was a significant effect of the treatment on the students' English reading achievement. In addition, the students' perception on the trained reading strategies and teaching materials were mostly positive. It means that there was an interrelation between the students' achievement and their perception on the trained reading strategies and teaching materials. In brief, this study demonstrated that chunking, elaborating, mapping, and summarizing strategies facilitated the students' English reading comprehension in expository texts.

In Indonesian context, English functions as a foreign language so it is not used as the official language in people's daily life. However, English is only a compulsory foreign language that must be taught at schools and the number of hours allocated for English is very limited. Therefore, for several reasons, reading textbooks written in English is still difficult skills for students in general and even for university students. In addition, there hasn't been any standard of teaching EAP to undergraduate students in Indonesia. Therefore, practically, the results of the study would be beneficial input for not only lecturers teaching EAP but also university students. The present researcher herself has employed the experimented reading strategies that facilitated students' English reading comprehension in content areas. Furthermore, theoretically, the results of the study enriched the previous research findings addressing teaching of English reading comprehension and reading strategies.

The results of the study suggest the following implications: 1) teachers should employ the experimented reading strategies, including activating students' prior knowledge, chunking, elaborative, mapping, and summarizing strategies, in teaching EAP because the strategies facilitate students' English reading comprehension. The benefit of employing those strategies will be felt by the students living in the country like Indonesia where English is not spoken and used in people's daily life; 2) teachers should use authentic expository texts from the students' discipline in the teaching of EAP because the teachers will easily activate the students' prior knowledge and elaborate their critical thinking and logical reasoning; 3 ) to motivate students, teachers should make reading pleasurable, allocate sufficient time for them to engage in reading activities, make them active and creative in responding to texts using discussion, encourage and value students' independent thinking as they read, write, speak, and listen (McLaughin \& Devoogd, 2004); 4) by employing the trained reading strategies using genre-based approach (Agustien, 2006), teachers automatically teach critical literacy lessons in which students apply the strategies after they have learned what they are and how to use them. The whole instruction process involves explaining the strategies, building knowledge of the text, demonstrating (modeling), practicing (joint construction and independent construction), and reflecting; 5) by asking students to summarize the texts using their own words, teachers would improve their reading and writing skills because there is a supportive and interactive relationship between the reading and writing processes. Hudelson (1994) emphasized, "At the heart of the language processes of reading and writing is the construction of meaning" (p.250). Research suggests that reading and writing skills support one another (DeFord, 1981; Elbow, 2004; Grabe, 1994) because readers see examples of how language is used while writers develop important writing skills through their understanding of the reading experience, and the process of writing helps students comprehend written language and control letters and texts; an understanding that they need for reading; 6) by applying elaborative processes, students are trained to have critical thinking and logical reasoning which are important for their future life. They have to apply and relate the ideas intended by the authors to the real life situations; and 7) further research utilizing different reading strategies should be conducted to explore other outcomes that might be more effective in EAP classrooms.

\section{References}

Agustien, H. I.R. (2006). "Genre-based approach and the 2004 English curriculum". A plenary paper resented at UPI National Seminar $27^{\text {th }}$ February 2006, Bandung.

Alexander, J. E. (1989). Teaching reading. Boston: Scott and Foresman Company.

Bergeson, T., Mayo, C.L., Lawson, B., \& Miller, J.A. (1998). Research into practice: An overview of reading research for Washington State. Washington: OSPI.

Bright, J.A., \& McGregor, G.P. (1986). Teaching English as a second language: Theory and techniques for the 
secondary stage. Singapore: Longman.

Carrell, P. L., \& Eisterhold, J. C. (1987). Schema theory and ESL reading pedagogy. In M.H. Long, \& J.C. Richards (Eds.). Methodology in TESOL (pp.218-232). Boston: Heinle \& Heinle Publishers.

Chastain, K. (1989). Developing second language reading skills: Theory and practice. New York: Harcowth Brace Javanovich Publisher.

Dadi, L.S. (2003). English reading comprehension for students of Economics. Bandung: Pusat Penerbitan UNISBA.

DeFord, D.E. (1981). Literacy: Reading, writing and other essentials. Language Arts, 58(6), 652-658.

Eskey, D.E. (2002). Reading and writing as both cognitive process and social behavior. In J.G. Carson, \& I. Leki (Eds.). Reading in the composition classroom in second language perspectives (pp. 221-226). Boston, MA: Heinle \& Heinle.

Grabe, W. (1994). Current developments in second language reading research language. In D.S. Byrd, N. Bailey, M.S. Gitterman (Eds.), Landmarks of American language and linguistics, Vol. 2. (pp.136-151). Washington: Office of English Language Program.

Hatch, E., \& Farhady, H. (1982). Research design and statistics for applied linguistics. London: Newbury House Publishers, Inc.

Hatch, E., \& Lazaraton, A. (1991). The research manual: Design and statistics for applied linguistics. NY: Newbury House Publishers.

Hudelson, S. (1994). Literacy development of second language children. In F. Genesee (Ed.), Educating second language children. Cambridge: Cambridge University Press

Hughes, A. (1989). Testing for language teachers. Cambridge: Cambridge University Press.

Hutchinson, T., \& Waters, A. (1987). English for specific purposes: A learning-centered approach. Cambridge: Cambridge University Press.

Irwin, J. W. (2006). Teaching reading comprehension processes. New Jersey: Prentice-Hall, Inc.

Lipson, M. Y., \& Wixson, K.K. (2003). Assessment \& instruction of reading and writing difficulty. Boston: Pearson Education, Inc.

Long, M. H., \& Richard, J. C. (1987). Methodology in TESOL. Boston: Heinle \& Heinle Publisher.

McKenna, M.C., \& Robinson, R.D. (1993). Teaching through text. London: Longman.

McLaughlin, M., \& DeVoogd, G.L. (2004). Critical literacy: Enhancing students' comprehension of text. New York: Scholastic.

Musthafa, B. (1997). Content area reading: Principles and strategies to promote independent learning. TEFLIN Journal, 8(1), 37-49.

Paul, D. (2007). Teaching English to children in Asia. Hong Kong: Longman.

Prapphal, K. (2003, January $\left.14^{\text {th }}\right)$. The relationship between reading strategies and language background of Thai science students in performing summary test. Retrieved from Pioneer.chula.ac.th/pkanchan/htm/sumtest.htm-24k

Richards, J. C. (2001). Curriculum development in language teaching. Cambridge: Cambridge University Press. http://dx.doi.org/10.1017/CBO9780511667220

Roe, B.D., Stoodt, B.D., \& Burns, P.C. (1987). Secondary school instruction: The content areas. Boston: Houghton Mifflin Company.

Sadtono, E. (1997). Bridging the gap, but is it Brigeable? Paper presented in the Second National Conference on English in High Schools and Universities in Indonesia. September $2^{\text {nd }}-4^{\text {th }}, 1997$. Bandung: ITB.

Soranastaporn, S. (2003, January $14^{\text {th }}$ ). A comparative study of reading comprehension strategies employed by ESP students. Thailand: Mahidol University. $\quad$ Retrieved from http://www.mahidol.ac.th/mahidol/sc/sclg/songsri/html-72k

Strevens, P. (1983). New orientations in the teaching of English. Oxford: Oxford University Press.

Sweet, A. P., Riley, R.W., Robinson, S.P., \& Conaty, J.C. (2007, January $\left.5^{\text {th }}\right)$. State of the art: Transforming ideas for teaching and learning to read. Retrieved from http://www.ed.gov/pubs/StateArt/Read/ idea8 html 
Taylor, B.M., \& Beach, R.W. (1984). The effect of text structure instruction on middle grade students' comprehension and production of expository text. Reading Research Quarterly, 19(2), 134-146. http://dx.doi.org/10.2307/747358

Vacca, R.T., \& Vacca J.A.L. (1993). Content area reading. $\left(4^{\text {th }}\right.$ Ed.). NY: Harper Collins College Publishers.

Weir, C.J. (1990). Communicative language testing. London: Prentice Hall.

Willis, J. (1986). Teaching English through English. Oxford: Oxford University Press.

\section{APPENDIXES}

\section{Appendix A}

Results of Tests obtained from Experimental and Control Groups

\begin{tabular}{|c|c|c|c|c|}
\hline \multirow{2}{*}{ NO } & \multicolumn{2}{|c|}{ Experimental Group } & \multicolumn{2}{|c|}{ Control Group } \\
\hline & Pretest & Posttest & Pretest & Posttest \\
\hline 1. & 15 & 29 & 5 & 19 \\
\hline 2. & 10 & 40 & 15 & 28 \\
\hline 3. & 21 & 37 & 16 & 35 \\
\hline 4. & 12 & 46 & 17 & 21 \\
\hline 5. & 27 & 42 & 20 & 24 \\
\hline 6. & 15 & 31 & 19 & 22 \\
\hline 7. & 23 & 46 & 15 & 32 \\
\hline 8. & 29 & 54 & 10 & 19 \\
\hline 9. & 26 & 42 & 8 & 14 \\
\hline 10. & 28 & 39 & 10 & 29 \\
\hline 11. & 26 & 53 & 19 & 27 \\
\hline 12. & 15 & 40 & 13 & 21 \\
\hline 13. & 17 & 49 & 15 & 27 \\
\hline 14. & 13 & 28 & 10 & 15 \\
\hline 15. & 21 & 51 & 11 & 39 \\
\hline 16. & 20 & 49 & 13 & 37 \\
\hline 17. & 16 & 44 & 21 & 23 \\
\hline 18. & 23 & 49 & 20 & 18 \\
\hline 19. & 20 & 53 & 18 & 19 \\
\hline 20. & 12 & 24 & 13 & 40 \\
\hline 21. & 9 & 36 & 19 & 34 \\
\hline 22. & 23 & 53 & 16 & 35 \\
\hline 23. & 2 & 21 & 14 & 32 \\
\hline 24. & 18 & 50 & 24 & 26 \\
\hline 25. & 31 & 41 & 17 & 32 \\
\hline 26. & 17 & 49 & 15 & 20 \\
\hline 27. & 21 & 39 & 21 & 37 \\
\hline 28. & 18 & 42 & 9 & 18 \\
\hline 29. & 18 & 25 & 20 & 24 \\
\hline 30. & 20 & 40 & 11 & 23 \\
\hline
\end{tabular}




\section{Appendix B}

An Example of the Procedures of Teaching Reading Comprehension to the Experimental Group

\begin{tabular}{|c|c|c|}
\hline Pre-reading Activities & During-reading Activities & After- reading Activities \\
\hline $\begin{array}{l}\text { 1. Distribute the text to the } \\
\text { students. } \\
\text { 2. Set the purpose of } \\
\text { reading which depends on } \\
\text { the titles of the text. } \\
\text { 3. Remind the students the } \\
\text { strategies of reading } \\
\text { employed. } \\
\text { 4. Survey the title and } \\
\text { subheadings (transforming } \\
\text { the subheadings into } \\
\text { questions), } \\
\text { 5. Activate students' prior } \\
\text { knowledge related to the } \\
\text { text by asking, for } \\
\text { example, "What do you } \\
\text { understand by the term } \\
\text { "economics"? What do } \\
\text { you think of the economy } \\
\text { in our country in general? } \\
\text { Ask them to provide } \\
\text { reasons for their judgment. } \\
6 . \text { Remind them the } \\
\text { language structure used in } \\
\text { the text (Building } \\
\text { knowledge of the text) }\end{array}$ & $\begin{array}{l}\text { 1. Preview the text } \\
\text { 2. Model chunking strategy } \\
\text { 3. Read for main ideas (Have students } \\
\text { work in groups to identify the } \\
\text { definition of economics, kind of } \\
\text { society's resources, scarcity, etc.) } \\
\text { 4. Scanning (Focus on content words) } \\
\text { 5. Locating references (integrative } \\
\text { processes) } \\
\text { 6. Mapping Strategy (help the students to } \\
\text { draw the keys of main ideas, } \\
\text { supporting ideas, details in a chart of } \\
\text { ideas on the board) } \\
\text { 7. Making Inferences (conclusion and } \\
\text { judgment) } \\
\text { 8. Monitoring (metacognitive) } \\
\text { Check their understanding of the text by } \\
\text { asking questions and locating the answers } \\
\text { on the text paragraph by paragraph and } \\
\text { match the ideas in the chart, or ask them } \\
\text { what ideas they remember; what the main } \\
\text { idea of the paragraph is. This is done up to } \\
\text { the last paragraph (study guide). } \\
\text { 9. Integrate new concepts with the existing } \\
\text { knowledge or the knowledge before } \\
\text { reading the text. }\end{array}$ & $\begin{array}{l}\text { 1. Evaluate the students' } \\
\text { predictions and ask them what } \\
\text { new knowledge they have after } \\
\text { reading the text. Then, ask them } \\
\text { to conclude and to make their } \\
\text { own judgment about the text. } \\
\text { 2. Elaborate new ideas from the } \\
\text { text to broader situation to } \\
\text { extend their critical thinking } \\
\text { and logical reasoning } \\
\text { (Elaborative process). E.g., In } \\
\text { what way does the government } \\
\text { overcome the problem of } \\
\text { scarcity with regard to fuel oil? } \\
\text { Ask them to find the examples } \\
\text { of production and consumption, } \\
\text { goods and services, etc. } \\
\text { 3. Ask the students to write the } \\
\text { summary of the text based on } \\
\text { the chart of ideas using their } \\
\text { own words and to end the } \\
\text { summary with their judgment } \\
\text { about the text }\end{array}$ \\
\hline
\end{tabular}

\section{Appendix C}

Pretest

$\begin{array}{ll}\text { Name } & : \\ \text { Group } & : \text { Experimental Group/ Control Group } \\ \text { Date } & :\end{array}$

1. Direction: Read the text carefully and answer the comprehension questions below on the answer sheet!

\section{Economics}

One way to define economics is to say that it is the social science that deals with such problems. Another definition, perhaps better known, is Alfred Marshall's: "Economics is a study of mankind in the ordinary business of life." A more penetrating definition might be the following: Economics is the study of the use of scarce resources to satisfy unlimited human wants. 


\section{Resources and Commodities}

A society's resources consist of natural endowments such as land, forests and minerals; human resources, both mental and physical; and manufactured aids to production such as tools, machinery and buildings. Economists call such resources factors of production because they are used to produce the outputs that people desire. The outputs produced are called commodities. They are divided into goods and services. Goods are tangible. (e.g., cars or shoes), and services are intangible (e.g., haircut or education).

People use goods and services to satisfy many of their wants. The act of making goods and services is called production, and the act of using them to satisfy wants is called consumption. Goods are valued for the services they provide. An automobile, for example, helps to satisfy its owner's desires for transportation, mobility, and possibly status.

\section{Scarcity}

For most of the world's 5 billion human beings, scarcity is real and ever present. In relation to desires (for more and better food, clothing, housing, schooling, entertainment, and so forth), existing resources are woefully inadequate. There are enough to produce only a small fraction of goods and services that are wanted.

Because resources are scarce, all societies face the problems of economics. Those are deciding what to produce and how much each person will consume. Societies differ in who makes the choices and how they are made, but the need to choose is common to all. Just as scarcity implies the need for choice, so choice implies the existence of cost. (Lipsey, et al., 1993, pp. 3-4)

1. What do you understand by the term 'economics'?

2. How many definitions of economics are there on the text?

3. What is the main idea of each definition mentioned?

4. What do a society's resources consist of?

5. Why do economists call the society's resources factors of production?

6. How do people benefit commodities? Provide examples!

7. Provide the examples of goods and services in the real life situation!

8. How can we value 'goods'? Provide examples!

9. What do you understand by consumption and production?

10. Provide three examples of production and consumption!

11. Using the contexts in the text, determine the reference of words printed in italics.
a. Economists call such resources factors of production because they are used to produce the outputs that people desire.
b. Goods are valued for the services they provide.
c. Those are deciding what to produce and how much each person will consume.

2. Direction: Based on your understanding about the text, answer the following questions!

1. This is about society's resources. Complete the table below! The first has been done as an example.

\begin{tabular}{|l|l|l|l|}
\hline No & Natural Resources & Human resources & Manufactured Aids \\
\hline 1. & Oil & Education & Building \\
2. & & & \\
3. & & & \\
4. & & & \\
5. & & & \\
\hline
\end{tabular}

2. "Goods are tangible and services are intangible" What does the statement mean?

3. What is the function of manufactured aids? Provide reasons! 
4. What is meant by 'scarcity' in economics? What does scarcity result in?

5. How can the problems resulted from this fact be overcome?

6. What do you think of economy in our country in general? (Very Good - Good - Bad -Very Bad - No idea). Provide reasons for your judgments!

7. Draw the chart of ideas of the text!

\section{Appendix D}

Posttest

Name :

Group : : Experimental Group/ Control Group

Date

1. Direction: Read the text carefully and answer the comprehension questions below on the answer sheet!

\section{Three Basic Methods of Leadership}

Whether you are discussing the shape of the earth or the origin of leaders, false ideas delay or interrupt progress and performance. We have gradually been setting aside some of our false ideas about leadership. Unfortunately, however, some of them are still with us. Here are few examples of such false ideas.

1. It is not right to concern yourself directly with matters for which a subordinate is responsible. You reduce his self-respect.

2. It is not right to issue unexplained orders. The right way is to discuss them and seek the opinions of others.

3. It is not right to demand obedience from a subordinate. This destroys his initiative.

Experience with the problems of leadership has shown instead that the right way often fails to produce results. The wrong way is often successful. Why is it true? The difficulty started with some of the first experiments on the subject of leadership, from which some false ideas developed.

In 1939, three American professors tried to examine what leadership really is. They organized two types of experimental groups. One type was led by an autocratic leader who determined policy; decided what was to be done and how it was to be done; gave individuals their tasks and selected the work companions for each member of the group; and was personal in expressing his praise, judgments, and general opinions. The second type of group was led by a so-called democratic leader who allowed the group to discuss questions of policy; encouraged group members to join in helping him solve problems; was fair in his remarks; and permitted individuals to choose work companions.

Then something happened which had not been planned or expected. One of the individuals playing the role of a democratic leader was creating a new feeling within his group. It was different from that established by other democratic leaders. He practiced almost no control over his people; permitted group members to manage largely by themselves; and made them try to solve their own problems as well as they could. As a result, this group began to act differently from the way the other democratic groups acted. Therefore, a third type of group was established to suit the method just described. This method came to be known as the Free-Rein method.

Observers noted differences in behavior, general feeling and accomplishment among the three types of groups. Autocratic method: The group members tended to disagree and argue. Some individuals became completely dependent upon the leader. When he was absent, activity was likely to stop entirely. Work progressed at only a fair rate. Democratic method: The individuals worked with one another in a friendly manner. Relations with the leader were freer, more natural. The work progressed steadily and continued even when the leader was absent. The Free-Rein method: Work progressed carelessly and at a slow rate. There was a lot of activity, but not much of it was productive. A great amount of time was lost in arguments and discussions between group members for purely personal reasons. How valuable were the results? The imagination and clear thinking of experimenters deserve the highest praise. These men gave us information of major importance in the study of how groups operate.

However, later studies showed that the information they produced was not always used correctly. For purposes of the experiment, the words "autocratic", "democratic", and "free-rein" had been given clear and exact meanings. But 
actually these words have many general meanings. In many cases, these meanings replaced those used in the experiments. One result was that people refused to accept anything that reminded them of autocratic and free-rein leadership. The term 'autocratic' suggested to them ruled by one man. It suggested an unreasonable, mean supervisor. The free-rein method suggested a leader who was weak, uncertain, and not responsible.

(Uris, A., 1992, pp. 14-15)

1. The text mentions about some false ideas about leadership. What are they?

2. It is mentioned that concerning yourself directly with matters for which a subordinate is responsible reduce his self-respect. What do you think?

3. It is not right to issue unexplained orders. What does it mean?

4. What are the main ideas of the first and second paragraphs?

5. Who conducted the experiment about leadership?

6. How many types of experimental groups are firstly organized in the experiment?

7. Why were the results of the experiment valuable for the science of Management?

Complete the following table with the three leader's characteristics of each group!

\begin{tabular}{|l|l|}
\hline Group & Leader's characteristics \\
\hline 8. Autocratic Leadership & 1. \\
& 2. \\
9. Democratic Leadership & 3. \\
& 1. \\
& 2. \\
10. Free-Rein Leadership & 3. \\
& 1. \\
& 2. \\
\hline
\end{tabular}

11. Using the text, write the reference of the words in italics in the table below!

d. It is not right to demand obedience from a subordinate. This destroys his initiative.

e. Unfortunately, however, some of them are still with us.

f. You reduce his self-respect.

g. The right way is to discuss them and seek the opinions of others.

2. Direction: Based on your understanding about the text, answer the following questions.

12. The text mentions three types of leadership, autocratic, democratic, and free-rein methods. What do you think the best one? Provide reasons!

Complete the following table with the noted differences in behavior, feeling, and accomplishment among the three groups in the experiment. 


\begin{tabular}{|l|l|}
\hline Group & Noted Differences \\
\hline 13. Autocratic leadership & 1. \\
& 2. \\
14. Democratic leadership & 3. \\
& 1. \\
15. Free-rein leadership & 2. \\
& 3. \\
& 1. \\
\hline
\end{tabular}

16. You must be familiar with the word "leader" now. Can you mention the highest executive and legislative leaders in the Republic of Indonesia? How is his or her style of leadership? Provide reasons!

17. What does "leadership" mean to you, then?

18. Draw the chart of ideas of the text! 